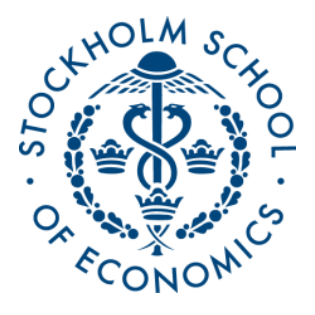

\title{
IS CHINA DIFFERENT? \\ A META-ANALYSIS OF EXPORT-LED GROWTH
}

\author{
Patrik Gustavsson Tingvall and Christer Ljungwall \\ Stockholm School of Economics
}

\section{CERC Working Paper 15 \\ April 2010}

Postal address: P.O. Box 6501, S-113 83 Stockholm, Sweden.

Office address: Holländargatan 30 Telephone: +46 87369360 Telefax: +46 8313017

E-mail: japan@hhs.se Internet: http://www.hhs.se/cerc 


\title{
Is China Different? A Meta-analysis of export-led growth
}

\author{
Patrik Gustavsson Tingvall ${ }^{\star}$ and Christer Ljungwall ${ }^{a}$
}

\begin{abstract}
Whether China has benefited more from exports than other countries has produced intensive debate. We analyze this question by performing a meta-analysis on a sample of 68 country-specific studies analyzing the link between exports and economic growth. The results show that exports have been more significant for growth in China than in other countries, even when China is compared to other transition/emerging economies.
\end{abstract}

Keywords: Meta-analysis; Exports; Economic growth; China

JEL Codes: F21; F43; O11; O53

\footnotetext{
* Corresponding author: Patrik Gustavsson Tingvall, Stockholm School of Economics, China Economic Research Center, Box 6501, 11383 Stockholm, Sweden. patrik.gustavsson@hhs.se Ph: +46(0)87369267.

${ }^{a}$ Christer.Ljungwall, affiliated researcher China Economic Research Center, Stockholm School of Economics.
} 


\section{Introduction}

The debate on whether export-oriented policies have the ability to spur economic growth has received much attention, although the evidence is mixed and inconclusive (Xu et al. 2009). Both the theoretical (Balassa, 1978, 1985) and the recent empirical literature disagree on the precise relation between exports and growth (Bhagwati and Srinivasan, 2002; Rodriguez and Rodrik, 2001). China is of particular interest in this discussion, since a host of empirical studies suggests that its growth performance since the early 1990s to a large extent has been export driven, see e.g. Mah (2005).

We analyze the relation between exports and growth by conducting a meta-analysis of relevant literature, covering a large number of countries at different stages of development. This enables us to investigate whether China differs from other countries in terms of how it is affected by exports. The paper is organized as follows: Section 2 discusses the model, data, and variables, section 3 presents the results and section 4 concludes.

\section{Model specification, data and variables}

Following Card and Krueger (1995) and Görg and Strobl (2001), we perform a metaanalysis on a sample of 68 country-specific studies that explore the link between exports and economic growth. Most meta-analyses in economics focus on publication bias (Stanley, Doucouliagos and Jarell 2006, Stanley 2008) but we ask whether the relation between exports and growth is more significant in China than in other countries. ${ }^{1}$

As our left-hand variable, we apply the $t$-statistic of the export variable, which gives us a dimensionless dependent variable. The $t$-statistic variable is then regressed on a number of study characteristics that are meta-independent and presumed to influence the outcome of the study. The following base-line regression is estimated using OLS:

\footnotetext{
${ }^{1}$ Other meta-analyses on export and growth/productivity include Martins and Yang, 2009 and Mookerjee 2006.
} 


$$
Y_{i}=\alpha_{0}+\sum_{k=1}^{K} \alpha_{k} X_{i k}+\varepsilon_{i} ; \quad i=1, \ldots, N \quad \varepsilon \sim \text { iid } N(0, \sigma)
$$

where $Y_{i}$ is the reported ' $t$ ' statistic, and " $X$ " contains a set of meta-independent variables that capture the characteristics of the empirical studies in the sample, so as to explain the variation in the $Y_{i}$ across studies, $\alpha$ are the set of coefficients to estimate, and $\varepsilon$ is the error term.

To improve the precision in the analysis and to handle interdependence, we extend (eq. 1) and estimate multi-level models which allow us to take into account the fact that results may co-vary within studies and countries (see Raudenbush,1993). Examples of studies using multi-level modeling in meta-analysis include Ljungwall and Tingvall (2010) in their analysis on FDI and economic growth and Kalaian and Raudenbush (1996) in their analysis on math performance and coaching. To the best of our knowledge, no earlier meta-analysis on exports has used multi-level regression techniques.

We project two sources for interdependency: country-specific effects (results from different studies but on the same country may be interrelated) and study-specific effects. A commonly used way to unilaterally handle such group effects is to allow for either country-specific random intercepts $v_{j}$ or random study effects $\zeta_{l}$ where foot index $j$ and I indicate country and study of origin respectively. To simultaneously control for those effects, we extend (eq. 1) into a two-level model with random intercepts by country and study, where the latter is assumed to be nested under the country level, represented by the random intercept $\zeta_{[j] l}$. Later we relax the assumption of nested data. Thus, the multi-level framework allows us to handle heterogeneity more fully than what is possible under a dummy variable framework, attributing different parts of the heterogeneity to different levels. ${ }^{2}$

\footnotetext{
${ }^{2}$ For further reading on multi-level models, see e.g., Hox (2002) and Verbeke and Molenberghs (2000).
} 


\subsection{Data and variables}

The data used in this analysis are drawn from 68 studies on export and growth, yielding a maximum of 263 observations. ${ }^{3}$ In comparison with other meta-analyses in economics, our sample size stands up well; for example, Görg and Strobl (2001) examined 21 studies yielding 25 observations, Diebel and Wooster (2006) gathered studies 32 and got 137 observations, and Meyer and Sinani (2009) included 66 studies resulting in 121 observations. ${ }^{4}$

As seen in Table A1, the distribution of $t$-values for China is shifted toward relative high values. The question is whether these seemingly high $t$-values can be explained by way of data and research design and whether the results for China are significantly different from the average for other countries. Our relatively large sample is not specifically constrained by problems related to inadequate degrees of freedom. The explanatory variables included are: Measures of exports (level or ratio of GDP or output); measures of productivity (level or growth); control for degrees of freedom; country type (developed, developing, and emerging/transition) ${ }^{5}$; study-specific co-variates (control for capital intensity, labor quality, type of data (firm-, industry-, or aggregated); time span; and period dummies.

\section{Results}

Table 1 reports results from the meta-regression analysis. The dependent variable in all equations is the $t$-statistic for exports. Estimation (1) is a minimalistic OLS model and in (2) a set of meta-independent study characteristics is appended. In estimation (3) we extend estimation (2) by adding a control for country type (developed, developing and transition/emerging). We note that throughout models $1-3$, the China dummy remains

\footnotetext{
${ }^{3}$ See http://www.hhs.se/search/person/pages/person.aspx?personid=136 for a listing of the studies included.

${ }^{4}$ We identify 15 outliers (t-val > 12) and estimations 1-7 are performed with outliers excluded.

${ }^{5}$ Country classification follow the FTSE index, www.ftse.com/Indices/Country Classification/index.jsp
} 
significant. In models 4-5, we examine whether the significance can be due to lack of control for interdependence, and we therefore cluster the standard errors by country (estimation 4) and study (estimation 5). In estimation (6), we extend the analysis to a two-level mixed model with random intercepts at the country and study level, where we first assume study effects to be nested under the country level. In Model (7), we increase the generality of the interdependence and estimate a two-way mixed model with non-nested random country and study specific effects. ${ }^{6}$ In Model (8), we reestimate this general model with extreme t-values included. None of these operations upset the results and the China dummy records a positive and significant coefficient throughout all specifications. The significance of the China dummy indicates that the impact of exports has been more significant for China than for other countries, even when we control for country type (indicating that the growth effect of exports has been more significant for China than for other transition/emerging economies). Contrary to e.g. Ljungwall and Tingvall (2010), and to some extent Görg and Stroble (2001) our results are not upset by the inclusion of extreme t-values.

- Table 1 about here -

\section{Concluding remarks}

Multi-level meta-analysis on a sample of 68 studies yielding a maximum of 263 observations that have reported results on the link between exports and economic growth suggests that exports have on average been more significant for China than for other countries. Thus, it is likely that the export-led growth strategy of China has successfully worked as a vehicle contributing to China's development.

\section{References}

Balassa, B., 1985. Exports, policy choices, and economic growth in developing countries after the 1973 oil shocks. Journal of Development Economics 18, 23-25.

\footnotetext{
${ }^{6}$ No hierarchical structure is imposed and a general interdependence structured is allowed for.
} 
Balassa, B., 1978. Export and economic growth: further evidence. Journal of Development Economics 5(2), 181-189.

Bhagwati, J., Srinivasan,T.N., 2002. Trade and poverty in poor countries. American Economic Review 92(2), 180-183.

Card, D., Krueger, A., 1995. Time series minimum wave studies: a meta-analysis. American Economic Review 85(2), 238-243.

Görg, H., Strobl, E., 2001. Multinational companies and productivity spillovers: a metaanalysis. Economic Journal 111, 723-739.

Diebel, D., Wooster, R., 2006. Productivity spillovers from foreign direct investment in developing countries: A meta-regression analysis. Conference paper, Department of Economics, University of Arkansas.

Hox, J., 2002. Multilevel Analysis: Techniques and Applications. Lawrence Erlbaum associates, Mahwah, NJ, USA.

Kalaian, H.A., Raudenbush, S.W., 1996. A multivariate mixed linear model for metaanalysis. Psychological Methods 1(3), 227-235.

Ljungwall, C., Tingvall, P., 2010. Is China different? A meta-analysis of the effects of foreign direct investment on domestic firms. Journal of Chinese Business and Economics Studies (Forthcoming).

Mah, J.S., 2005. Export expansion, economic growth and causality in China, Applied Economics Letters, 12, 105-107.

Martins, S.M., Yang, Y., 2009. The impact of exporting on firm productivity: A metaanalysis. Review of World Economics, 145(3), 431-445.

Meyer, K., E, Sinani., 2009. When and where does foreign direct investment generate positive spillovers? A meta-analysis. Journal of International Business Studies 40(7), 1075-1094.

Mookerjee, R., 2006. A meta-analysis of the export growth hypothesis. Economics Letters, 91, 395-401.

Raudenbush, S.W., 1993. A crossed random effects model for unbalanced data with applications in cross-sectional longitudinal research. Journal of Educational and Behavioral Statistics 18(4), 321-349.

Rodriguez,F., Rodrik, D., 2001. Trade policy and economic growth: a skeptics' guide to the evidence. In Bernan, B., Rogoff, K. (eds), NBER Macroeconomics Annual 2000, MIT Press, Cambridge, MA, pp. 261-325.

Stanley T.D., 2008. "Meta-Regression Methods for Detecting and Estimating Empirical Effects in the Presence of Publication Selection". Oxford Bulletin of Economics and Statistics, 70(1), 103-127.

Stanley T.D., Doucouliagos, C.H., Jarell, S.B., 2006. "Meta-Regression analysis of the Socio-Economics of Economics Research". Deakin University, School of accounting and finance working paper series 2006/21.

Verbeke, G., Molenberghs, G., 2000. Linear mixed models for longitudinal data. Springer, New York. 
Xu, D-q., Ljungwall, C., Xin, L,. 2009. The road to end poverty: A comparison of development strategies between China and India. China Mechanic Press, Beijing.

\section{Appendix}

Table 1. Meta-regression analysis on export and growth, Dependent variable: $t$-statistic

\begin{tabular}{|c|c|c|c|c|c|c|c|c|}
\hline & $\begin{array}{l}\text { M1. } \\
\text { OLS }\end{array}$ & $\begin{array}{l}\text { M2. } \\
\text { OLS }\end{array}$ & $\begin{array}{l}\text { M3. } \\
\text { OLS }\end{array}$ & $\begin{array}{c}\text { M4. } \\
\text { OLS } \\
\text { cluster } \\
(A)\end{array}$ & $\begin{array}{c}\text { M5. } \\
\text { OLS } \\
\text { cluster } \\
(B)\end{array}$ & $\begin{array}{c}\text { M6. } \\
2 \text { Ivl. } \\
\text { random } \\
\text { intercept } \\
\text { (C) }\end{array}$ & $\begin{array}{c}\text { M7. } \\
\text { Two } \\
\text { way. } \\
\text { Mixed } \\
\text { model }^{(D)}\end{array}$ & $\begin{array}{c}\text { M8. } \\
\text { Unrestr. } \\
t \text {-values } \\
(\mathrm{E})\end{array}$ \\
\hline $\begin{array}{l}\text { China } \\
\text { dummy }\end{array}$ & $\begin{array}{l}2.5991 \\
(2.25)^{* *}\end{array}$ & $\begin{array}{l}2.9675 \\
(2.04)\end{array}$ & $\begin{array}{l}3.9032 \\
(2.54)\end{array}$ & $\begin{array}{l}3.9032 \\
(1.92)\end{array}$ & $\begin{array}{l}3.9032 \\
(1.89)^{*}\end{array}$ & $\begin{array}{l}2.7595 \\
(1.66)\end{array}$ & $\begin{array}{l}2.4709 \\
(2.38)\end{array}$ & $\begin{array}{l}2.3137 \\
(1.68)\end{array}$ \\
\hline $\ln \sqrt{D G F}$ & $\begin{array}{r}-0.1291 \\
(-0.40)\end{array}$ & $\begin{array}{l}-1.2960 \\
(-1.99)^{* *}\end{array}$ & $\begin{array}{l}-1.4774 \\
(-2.71)^{* * *}\end{array}$ & $\begin{array}{l}-1.4774 \\
(-1.65)\end{array}$ & $\begin{array}{c}-1.4774 \\
(-1.40)\end{array}$ & $\begin{array}{l}-1.1322 \\
(-2.06)^{* *}\end{array}$ & $\begin{array}{l}-0.9288 \\
(-1.72)\end{array}$ & $\begin{array}{l}-0.5551 \\
(-0.40)\end{array}$ \\
\hline $\begin{array}{l}\text { Aggregated } \\
\text { data }\end{array}$ & $\begin{array}{c}-1.0182 \\
(-1.55)\end{array}$ & $\begin{array}{l}-2.6767 \\
(-2.25)\end{array}$ & $\begin{array}{c}-2.8361 \\
(1.24)\end{array}$ & $\begin{array}{r}-2.8361 \\
(-1.33)\end{array}$ & $\begin{array}{l}-2.8361 \\
(-1.10)\end{array}$ & $\begin{array}{c}-1.5911 \\
(-1.09)\end{array}$ & $\begin{array}{c}-1.3305 \\
(-1.08)\end{array}$ & $\begin{array}{c}-1.3125 \\
(-0.76)\end{array}$ \\
\hline $\begin{array}{l}\text { Industry } \\
\text { data }\end{array}$ & $\begin{array}{l}-3.7524 \\
(-3.33)^{* \star \star}\end{array}$ & $\begin{array}{l}-7.3912 \\
(-3.04)^{* * *}\end{array}$ & $\begin{array}{l}-7.3810 \\
(-2.94)^{* * *}\end{array}$ & $\begin{array}{l}-7.3810 \\
(-1.70)^{*}\end{array}$ & $\begin{array}{c}-7.3810 \\
(-1.56)\end{array}$ & $\begin{array}{l}-5.5000 \\
(-2.48)^{* *}\end{array}$ & $\begin{array}{l}-5.2630 \\
(-2.03)^{* *}\end{array}$ & $\begin{array}{l}-6.7352 \\
(-2.28)^{* \star}\end{array}$ \\
\hline Tot export & .. & $\begin{array}{c}0.2694 \\
(0.75)\end{array}$ & $\begin{array}{c}0.2539 \\
(0.55)\end{array}$ & $\begin{array}{c}0.2539 \\
(0.45)\end{array}$ & $\begin{array}{c}0.2538 \\
(0.29)\end{array}$ & $\begin{array}{c}0.1385 \\
(0.22)\end{array}$ & $\begin{array}{c}0.7278 \\
(1.00)\end{array}$ & $\begin{array}{c}0.3202 \\
(0.59)\end{array}$ \\
\hline $\begin{array}{l}\text { Productivity } \\
\text { growth dum. }\end{array}$ & .. & $\begin{array}{l}-0.9471 \\
(-1.03)\end{array}$ & $\begin{array}{l}-0.9292 \\
(-1.13)\end{array}$ & $\begin{array}{c}-0.9292 \\
(-1.02)\end{array}$ & $\begin{array}{c}-0.9292 \\
(-0.67)\end{array}$ & $\begin{array}{c}-1.0839 \\
(-1.49)\end{array}$ & $\begin{array}{c}-1.0949 \\
(-1.07)\end{array}$ & $\begin{array}{c}-2.5131 \\
(-1.14)\end{array}$ \\
\hline $\begin{array}{l}\text { Capital control } \\
\text { dum. }\end{array}$ & .. & $\begin{array}{c}0.0054 \\
(0.01)\end{array}$ & $\begin{array}{c}-0.0955 \\
(0.15)\end{array}$ & $\begin{array}{c}-0.0955 \\
(-0.12)\end{array}$ & $\begin{array}{c}-0.0955 \\
(-0.09)\end{array}$ & $\begin{array}{l}-0.4803 \\
(-0.82)\end{array}$ & $\begin{array}{c}0.1266 \\
(0.26)\end{array}$ & $\begin{array}{l}-2.5020 \\
(-2.74)^{* * *}\end{array}$ \\
\hline $\begin{array}{l}\text { Labor quality } \\
\text { dum. }\end{array}$ & .. & $\begin{array}{l}4.2602 \\
(1.89)\end{array}$ & $\begin{array}{l}4.3689 \\
(1.65)\end{array}$ & $\begin{array}{c}4.3689 \\
(1.13)\end{array}$ & $\begin{array}{c}4.3689 \\
(0.99)\end{array}$ & $\begin{array}{l}4.1442^{*} \\
(2.27)^{* \star}\end{array}$ & $\begin{array}{l}3.9169 \\
(2.41)\end{array}$ & $\begin{array}{l}7.4802 \\
(1.89)^{*}\end{array}$ \\
\hline Industry dum. &.. & $\begin{array}{c}4.1599 \\
(1.19)\end{array}$ & $\begin{array}{c}4.8631 \\
(1.47)\end{array}$ & $\begin{array}{c}4.8631 \\
(0.98)\end{array}$ & $\begin{array}{c}4.8631 \\
(1.14)\end{array}$ & $\begin{array}{c}2.7517 \\
(1.25)\end{array}$ & $\begin{array}{l}1.8999 \\
(0.79)\end{array}$ & $\begin{array}{c}4.0032 \\
(0.75)\end{array}$ \\
\hline Period dum. & .. & $\begin{array}{l}-2.8811 \\
(-1.71)^{*}\end{array}$ & $\begin{array}{l}-3.1425 \\
(-1.94)^{*}\end{array}$ & $\begin{array}{c}-3.1425 \\
(-1.44)\end{array}$ & $\begin{array}{l}-3.1425 \\
(-1.76)\end{array}$ & $\begin{array}{l}-1.9177 \\
(-1.84)\end{array}$ & $\begin{array}{l}-1.9993 \\
(-1.80)^{*}\end{array}$ & $\begin{array}{l}-2.6803 \\
(-1.86)^{*}\end{array}$ \\
\hline Time span &.. & $\begin{array}{l}-0.0690 \\
(-2.35)^{* *}\end{array}$ & $\begin{array}{l}-0.0647 \\
(-1.92)^{*}\end{array}$ & $\begin{array}{l}-0.0647 \\
(-1.65)^{*}\end{array}$ & $\begin{array}{c}-0.0647 \\
(-1.54)\end{array}$ & $\begin{array}{l}-0.0792 \\
(-2.65)^{* * *}\end{array}$ & $\begin{array}{l}-0.0775 \\
(-2.11)^{* *}\end{array}$ & $\begin{array}{c}-0.0294 \\
(-0.24)\end{array}$ \\
\hline $\begin{array}{l}\text { Country type } \\
\text { Model p-val } \\
\text { Linear p-val }\end{array}$ & $\begin{array}{l}\text { No } \\
. .\end{array}$ & $\begin{array}{l}\text { No } \\
. . \\
. .\end{array}$ & $\begin{array}{l}\text { Yes } \\
. . \\
. .\end{array}$ & $\begin{array}{l}\text { Yes } \\
. . \\
. .\end{array}$ & $\begin{array}{c}\text { Yes } \\
. .\end{array}$ & $\begin{array}{l}\text { Yes } \\
0.01 \\
0.00\end{array}$ & $\begin{array}{l}\text { Yes } \\
0.00 \\
0.00\end{array}$ & $\begin{array}{l}\text { Yes } \\
0.00 \\
1.00\end{array}$ \\
\hline $\begin{array}{l}\mathrm{R}^{2} \\
\text { Obs. }\end{array}$ & $\begin{array}{l}0.05 \\
248\end{array}$ & $\begin{array}{l}0.16 \\
248\end{array}$ & $\begin{array}{l}0.18 \\
248\end{array}$ & $\begin{array}{l}0.18 \\
248\end{array}$ & $\begin{array}{l}0.18 \\
248\end{array}$ & 248 & 248 & 263 \\
\hline
\end{tabular}

Note:"," significant at the $1 \%, 5 \%$ and $10 \%$ level, respectively. $t$-values in parenthesis (.) based on bootstrapped standard errors. Model (7) is not bootstrapped due to lack of convergence.

(A) Standard errors clustered by country.

(B) Standard errors clustered by study.

(C) Random intercepts with study effects nested under the country level.

(D) Mixed model with non-nested random country and study specific effects.

(E) Same specification as model M7 but with extreme $t$-values included ( $t$-value $>12$ ).

Table A1. Distribution of $t$-values, by percentile.

\begin{tabular}{ccc}
\hline & Non-China & China \\
\hline $\mathbf{P}_{25}$ & $t=0.37$ & $t=2.58$ \\
$\mathbf{P}_{50}$ & $t=2.00$ & $t=4.10$ \\
$\mathbf{P}_{75}$ & $t=3.74$ & $t=9.96$ \\
\hline
\end{tabular}

